DOI: $10.15193 /$ zntj/2020/124/349

\author{
MAGDALENA GAJEWSKA, BEATA BARTODZIEJSKA, \\ ANNA SZOSLAND-FAŁTYN
}

\title{
WYKORZYSTANIE PROCESÓW FERMENTACYJNYCH DO OPRACOWANIA INNOWACYJNEJ METODY OTRZYMYWANIA OCTU JABŁKOWEGO O WŁAŚCIWOŚCIACH PROZDROWOTNYCH
}

\author{
Streszczenie
}

Octy owocowe uzyskane metodami fermentacyjnymi stanowią atrakcyjny rodzaj żywności funkcjonalnej, która znajduje coraz większe uznanie wśród konsumentów ze względu na swoje walory prozdrowotne. Celem badań było opracowanie innowacyjnej technologii produkcji octu owocowego z wykorzystaniem lokalnych szczepów mikroorganizmów, pochodzących z kolekcji kultur Instytutu Biotechnologii Przemysłu Rolno-Spożywczego (IBPRS). Surowcem do biosyntezy octu były naturalne, tłoczone na zimno soki jabłkowe pozyskiwane od rolników i małych przedsiębiorców rolnych z województwa łódzkiego, śląskiego oraz mazowieckiego. Soki poddano wstępnym badaniom mikrobiologicznym i fizykochemicznym, polegającym na określeniu: liczby drożdży i pleśni, zawartości ekstraktu ogólnego, cukrów ogółem, kwasowości i pH oraz zawartości kadmu i ołowiu. Pierwszy etap produkcji octu stanowiła beztlenowa fermentacja soków jabłkowych, w wyniku której otrzymano wina, w których oznaczono zawartość alkoholu i cukrów. Drugim etapem była biosynteza kwasu octowego z użyciem win jabłkowych oraz szczepów bakterii octowych Acetobacter pasterianus $\mathrm{O} 4$ i Acetobacter pasterianus MW3. Podczas procesu biosyntezy oznaczano zawartość alkoholu oraz moc powstającego octu. Opracowana w Zakładzie Jakości Żywności IBPRS technologia otrzymywania octu owocowego umożliwiła uzyskanie produktu o mocy w zakresie $3,3 \div 4,5$ g kwasu octowego w $100 \mathrm{~cm}^{3}$, pozbawionego chemicznych konserwantów, o wyjątkowych walorach smakowo-zapachowych, charakteryzującego się wysoką jakością i wartością żywieniową.

Słowa kluczowe: ocet jabłkowy, żywność funkcjonalna, proces fermentacji, Acetobacter pasterianus $\mathrm{O} 4$, Acetobacter pasterianus MW3

Dr n. med. M. Gajewska, dr B. Bartodziejska, dr A. Szosland-Fałtyn, Zakład Jakości Żywności, Al. Marszałka J. Pitsudskiego 84, 92-202 Łódź, Instytut Biotechnologii Przemysłu Rolno-Spożywczego im. Prof. W. Dabrowskiego w Warszawie, ul. Rakowiecka 36, 02-532 Warszawa.

Kontakt: magdalena.gajewska@ibprs.pl 


\section{Wprowadzenie}

Ocet jest jednym z najstarszych produktów fermentacyjnych, znanym od tysięcy lat. Istnieje wiele udokumentowanych informacji, że był ulubioną przyprawą, środkiem konserwującym oraz orzeźwiającym napojem w starożytnej Babilonii $[1,5,14]$. Od wieków znajduje również zastosowanie w medycynie ludowej do leczenia różnych infekcji. Niszczy chorobotwórcze bakterie w układzie pokarmowym, jest skuteczny przy infekcjach układu moczowego, łagodzi i likwiduje objawy dny moczanowej i reumatoidalnego zapalenia stawów, reguluje poziom cholesterolu, wzmacnia naczynia krwionośne, redukuje tkankę tłuszczową, poprawia kondycję fizyczną oraz wzmacnia układ immunologiczny $[6,17,29]$. Ocet jest produktem używanym w codziennym życiu. Służy do zakwaszania smaku potraw. Jest składnikiem sosów do sałatek, ketchupów czy musztard. Stosuje się go również w kosmetyce i medycynie. W zależności od surowca użytego do produkcji wyróżnia się różne jego odmiany: biały, winny, ziemniaczany, spirytusowy, destylowany, balsamiczny, ryżowy, owocowy, kokosowy, kombucha, szampański, sherry itp. Ocet jest przezroczystą cieczą zawierającą zwykle $4 \div 15 \%$ kwasu octowego. Wytwarzany może być metodą rozcieńczania kwasu octowego, uzyskanego syntetycznie w procesie utleniania aldehydu octowego lub w suchej destylacji drewna bądź metodą fermentacji octowej z wykorzystaniem bakterii fermentacji octowej. W przemyśle spożywczym wykorzystywany jest zarówno ocet fermentacyjny, jak i syntetyczny $[1,2]$.

Octy owocowe należą do produktów otrzymywanych na drodze beztlenowej fermentacji alkoholowej owoców przy użyciu drożdży, a następnie biosyntezy kwasu octowego, którą przeprowadzają tlenowe bakterie kwasu octowego (AAB - Acetic Acid Bacteria). Są to nieprzetrwalnikujące, katalazo-dodatnie i oksydazo-ujemne pałeczki występujące pojedynczo lub tworzące łańcuszki. Głównym metabolitem produkowanym przez AAB jest kwas octowy. Biosynteza tego związku następuje w wyniku utleniania alkoholu etylowego, a proces ten jest katalizowany przez dwa enzymy znajdujące się w błonie cytoplazmatycznej bakterii octowych. Pierwszym etapem biosyntezy kwasu octowego jest oksydacja etanolu do aldehydu octowego z udziałem enzymu dehydrogenazy alkoholowej (ADH) (E.C.1.1.1.1). Następnie aldehyd ulega utlenieniu przez dehydrogenazę aldehydową (ALDH) (E.C.1.2.1.3) do produktu końcowego. Optymalne warunki syntezy kwasu octowego przez bakterie to $\mathrm{pH}$ o zakresie $3 \div 4$ i temperatura ok. $30^{\circ} \mathrm{C}[3,10]$.

W Polsce powszechnie używany jest 10-procentowy ocet spirytusowy, którego sprzedaż w sezonie letnio-jesiennym wzrasta nawet trzykrotnie. Ze względu na dobrą koniunkturę w grupie octów smakowych i owocowych, wiele octowni zaczyna wprowadzać je do swojej oferty. Ocet owocowy jest powszechnie stosowany jako konserwant żywności, gdyż skutecznie hamuje rozwój mikroorganizmów zanieczyszczających produkty spożywcze $[5,6]$. Uzyskany w procesach fermentacji ocet owocowy jest 
bogaty w kwasy organiczne: octowy, cytrynowy, mlekowy, bursztynowy i jabłkowy, enzymy, pektyny oraz przeciwutleniające związki fenolowe (kwas galusowy, kawowy, chlorogenowy, katechiny, epikatechiny) o potwierdzonych walorach prozdrowotnych $[4,9,13,14,15,16,18,30]$. Zawiera także niezbędne we wszystkich procesach życiowych składniki, takie jak: aminokwasy, pierwiastki (żelazo, fluor, potas, wapń, miedź, magnez, sód, fosfor, siarkę, krzem) oraz witaminy, w tym: $\mathrm{B}_{1}, \mathrm{~B}_{2}, \mathrm{~B}_{6}, \mathrm{C}, \mathrm{E}, \mathrm{P}$, A $[4,5,12]$. Zdecydowana większość octów dostępnych na rynku produkowana jest najczęściej z dodatkiem chemicznych środków konserwujących.

Konsumenci przywiązują coraz większą wagę do prozdrowotnego odżywiania i trybu życia, więc chętniej sięgają po żywność o wysokiej jakości, jak najmniej przetworzoną, bezpieczną i zawierającą substancje bioaktywne. Z kolei producenci żywności działają $\mathrm{w}$ warunkach silnej konkurencji, stąd prześcigają się we wprowadzaniu innowacyjnych produktów na bazie naturalnych surowców, wytwarzanych z zastosowaniem tradycyjnych receptur, bez dodatku środków konserwujących. Na rynku pojawily się octy owocowe wytwarzane metodami tradycyjnymi poprzez poddanie fermentacji pulpy jabłkowej, powstałej z rozdrobnienia całych owoców, bez użycia drożdży $[5,17,19]$.

Dodatkowym bodźcem do podejmowania problematyki fermentacji są oczekiwania rolników oraz małych i średnich przedsiębiorców rolnych, którzy dysponują nadmiarem owoców, jak również soków owocowych. Potrzebują więc technologii, która umożliwiłaby im zwiększenie stopnia wykorzystania lokalnych surowców i ograniczenie ich marnotrawstwa, wynikającego z krótkiego terminu przydatności do spożycia.

Celem badań podjętych w Zakładzie Jakości Żywności Instytutu Biotechnologii Przemysłu Rolno-Spożywczego (IBPRS) było opracowanie innowacyjnej technologii produkcji octu owocowego z wykorzystaniem lokalnych szczepów mikroorganizmów.

\section{Material i metody badań}

Surowcem do opracowania innowacyjnej technologii produkcji octu jabłkowego były naturalne, tłoczone na zimno soki jabłkowe (niepasteryzowane i pasteryzowane z zastosowaniem niskotemperaturowej pasteryzacji) pozyskane od 4 małych przedsiębiorców rolnych z województwa łódzkiego, śląskiego oraz mazowieckiego. Przebadano po 5 próbek soków z każdego przedsiębiorstwa.

Na podstawie badań mikrobiologicznych i fizykochemicznych, prowadzonych na bieżąco podczas całego cyklu, w warunkach laboratoryjnych opracowano dwuetapową metodę innowacyjnej technologii produkcji octu owocowego, która będzie wdrożona na skalę przemysłową w gospodarstwach rolnych.

Pierwszy etap stanowiła beztlenowa fermentacja w temp. $25^{\circ} \mathrm{C}$ soków jabłkowych, z wykorzystaniem wyselekcjonowanych szlachetnych drożdży winiarskich rasy Tokay, przeznaczonych do produkcji win białych. Przed rozpoczęciem procesu fer- 
mentacji pozyskane soki poddawano wstępnym badaniom mikrobiologicznym i fizykochemicznym, podczas których oznaczano liczbę drożdży i pleśni - PN-ISO 7954:1999 [20] oraz zawartość: ekstraktu ogólnego - PN-EN 12143:2000 [21] i cukrów ogółem - PN-A-75101-07:1990 [22]. Ponadto oznaczano: kwasowość ogólną PN-EN 12147:2000 [23] i wartość pH - PN-EN 1132:1999 [24] oraz zawartość metali ciężkich: kadmu i ołowiu - PN-EN 14082:2004 [25]. Powstałe w procesie fermentacji wina jabłkowe analizowano na zawartości alkoholu - PN-A-79120-04:1990 [26] oraz cukrów ogółem - PN-A-79120-06:1990 [27].

Drugi etap stanowiła biosynteza kwasu octowego w temp. $30{ }^{\circ} \mathrm{C}$, do której używano otrzymanych win jabłkowych oraz szczepów bakterii octowych Acetobacter pasterianus $\mathrm{O} 4$ i Acetobacter pasterianus MW3, pochodzących z własnej kolekcji kultur IBPRS. Szczepy te charakteryzowały się korzystnymi cechami biotechnologicznymi, opornością na wysokie stężenia kwasu octowego występującego $\mathrm{w}$ procesie technologicznym oraz wysoką aktywnością i zdolnością namnażania. Podczas procesu biosyntezy oznaczano zawartość alkoholu według PN-A-79120-04:1990 [26] oraz moc powstającego octu zgodnie z metodyką opisaną przez Czubę [8]. Przeprowadzano także ocenę sensoryczną uzyskanych octów jabłkowych za pomocą testu opisowego według prostej procedury własnej PS-13 edycja 1 [28]. Oceniano wygląd, klarowność, barwę oraz smak i zapach octów.

Uzyskane wyniki badań fizykochemicznych i mikrobiologicznych opracowano statystycznie przy użyciu programu komputerowego Statistica 10. Zastosowano jednoczynnikową analizę wariancji (ANOVA). Istotność różnic pomiędzy wartościami średnimi weryfikowano testem Tukeya przy $\mathrm{p}=0,05$.

\section{Wyniki i dyskusja}

Wyniki badań soków jabłkowych stanowiących surowiec do produkcji octów owocowych zestawiono w tab. 1. Soki jabłkowe nie były zanieczyszczone kadmem i ołowiem, charakteryzowały się kwasowością w zakresie $0,32 \div 0,56 \mathrm{~g} / 100 \mathrm{~cm}^{3}$ w przeliczeniu na kwas cytrynowy, $\mathrm{pH}-3,45 \div 3,93$, zawartością ekstraktu ogólnego w zakresie $11,4 \div 15,1 \%$. Zawartość cukrów wynosiła $10,5 \div 14,7 \mathrm{~g} / 100 \mathrm{~cm}^{3}$, drożdże i pleśnie były nieobecne w badanych próbkach. Wartości $\mathrm{pH}$ w sokach nie różniły się statystycznie istotnie $(\mathrm{p} \leq 0,05)$, natomiast soki z przedsiębiorstwa rolnego II różniły się statystycznie istotnie pod względem zawartości ekstraktu ogólnego i cukrów ogółem od soków z pozostałych przedsiębiorstw. Ponadto soki z przedsiębiorstwa rolnego IV charakteryzowały się istotnie niższą kwasowością w porównaniu z sokami z przedsiębiorstwa I i III.

Soki charakteryzowały się odpowiednimi cechami fizykochemicznymi i mikrobiologicznymi, co umożliwiło przeprowadzenie procesu fermentacji alkoholowej, z wykorzystaniem wyselekcjonowanych szlachetnych drożdży winiarskich rasy Tokay. 
Podczas procesu fermentacji kontrolowano zawartość cukrów oraz zawartość alkoholu. Brak cukru oznaczał koniec procesu fermentacji alkoholowej, natomiast zawartość alkoholu w uzyskanym winie przekładała się na uzyskaną w dalszym procesie moc octu. W wyniku fermentacji alkoholowej soków jabłkowych uzyskano wina charakteryzujące się zawartością alkoholu w zakresie $6,81 \div 10,84 \%$, przy czym różnice pomiędzy próbami pod względem tego parametru były statystycznie istotne. Znikoma zawartość cukrów w winach świadczyła o całkowitym przefermentowaniu soków (tab. 2).

Tabela 1. Wyniki badań soków jabłkowych

Table 1. Analysis results of apple juices

\begin{tabular}{|l|c|c|c|c|}
\hline \multicolumn{1}{|c|}{ Parametr / Parameter } & $\begin{array}{c}\text { Przedsięb. } \\
\text { rolne I } \\
\text { Farm I }\end{array}$ & $\begin{array}{c}\text { Przedsięb. } \\
\text { rolne II } \\
\text { Farm II }\end{array}$ & $\begin{array}{c}\text { Przedsięb. } \\
\text { rolne III } \\
\text { Farm III }\end{array}$ & $\begin{array}{c}\text { Przedsięb. } \\
\text { rolne IV } \\
\text { Farm IV }\end{array}$ \\
\hline $\begin{array}{l}\text { Liczba drożdży i pleśni [jtk/ } \mathrm{ml}] \\
\text { Count of yeast and mould [cfu/ml] }\end{array}$ & $<1$ & $<1$ & $<1$ & $<1$ \\
\hline $\begin{array}{l}\text { Zawartość ekstraktu ogólnego } \\
\text { Content of total extract [g/100 cm }{ }^{3} \text { ] }\end{array}$ & $14,3 \pm 0,6$ & $11,4 \pm 0,5$ & $13,8 \pm 0,5$ & $15,1 \pm 0,5$ \\
\hline $\begin{array}{l}\text { Zawartość cukrów ogółem } \\
\text { Content of total sugar [g/100 cm }{ }^{3} \text { ] }\end{array}$ & $12,8 \pm 1,6$ & $10,5 \pm 1,3$ & $13,5 \pm 1,5$ & $14,7 \pm 1,9$ \\
\hline $\begin{array}{l}\text { Kwasowość ogólna } \\
\text { Total acidity [g/100 cm }{ }^{3} \text { ] }\end{array}$ & $0,56 \pm 0,03$ & $0,40 \pm 0,02$ & $0,48 \pm 0,03$ & $0,32 \pm 0,02$ \\
\hline Wartość pH / pH value & $3,48 \pm 0,30$ & $3,56 \pm 0,32$ & $3,45 \pm 0,31$ & $3,93 \pm 0,36$ \\
\hline Zawartość Cd/ Cd content [mg/kg] & $<0,003^{*}$ & $<0,003^{*}$ & $<0,003^{*}$ & $<0,003^{*}$ \\
\hline Zawartość Pb / Pb content [mg/kg] & $<0,020^{*}$ & $<0,020^{*}$ & $<0,020^{*}$ & $<0,020^{*}$ \\
\hline
\end{tabular}

Objaśnienia / Explanatory notes:

W tabeli przedstawiono wartości średnie \pm odchylenia standardowe / Table shows mean values \pm standard deviations; $\mathrm{n}=5 ;(*)$ - granica oznaczalności $\mathrm{Cd}$ i $\mathrm{Pb} /$ limit of determination of $\mathrm{Cd}$ and $\mathrm{Pb}$.

Tabela 2. Wyniki badań win uzyskanych w procesie fermentacji soków jabłkowych

Table 2. Analysis results of wines produced by means of fermentation process of apple juices

\begin{tabular}{|l|c|c|c|c||}
\hline \multicolumn{1}{|c|}{ Parametr / Parameter } & $\begin{array}{c}\text { Przedsięb. } \\
\text { rolne I } \\
\text { Farm I }\end{array}$ & $\begin{array}{c}\text { Przedsięb. } \\
\text { rolne II } \\
\text { Farm II }\end{array}$ & $\begin{array}{c}\text { Przedsięb. } \\
\text { rolne III } \\
\text { Farm III }\end{array}$ & $\begin{array}{c}\text { Przedsięb. } \\
\text { rolne IV } \\
\text { Farm IV }\end{array}$ \\
\hline $\begin{array}{l}\text { Zawartość cukrów ogółem } \\
\left.\text { Content of total sugar [g/100 cm } \mathrm{cm}^{3}\right]\end{array}$ & $<1^{*}$ & $1,4 \pm 0,3$ & $<1^{*}$ & $<1^{*}$ \\
\hline $\begin{array}{l}\text { Zawartość alkoholu } \\
\text { Content of alcohol [\%] }\end{array}$ & $6,81 \pm 0,11$ & $7,95 \pm 0,16$ & $8,80 \pm 0,27$ & $10,84 \pm 0,22$ \\
\hline
\end{tabular}

Objaśnienia / Explanatory notes:

(*) - granica oznaczalności cukrów / limit of determination for sugars

Pozostałe objaśnienia jak pod tab. 1. / Other explanatory notes as in Tab. 1. 
W kolejnym etapie przeprowadzono biosyntezę kwasu octowego w temp. $30^{\circ} \mathrm{C}$, w której substratem były wina wytworzone w wyniku fermentacji soków jabłkowych, przy użyciu szczepów bakterii octowych Acetobacter pasterianus O4 i Acetobacter pasterianus MW3. Podczas procesu biosyntezy analizowano zawartość alkoholu oraz moc powstającego octu. Wydajność produkcji kwasu octowego w znacznym stopniu zależy od temperatury i napowietrzania, dlatego oba parametry były również kontrolowane i regulowane. Nadmiar tlenu prowadził do tzw. nadoksydacji, czyli utleniania substratu do ditlenku węgla i wody, co obniżało wydajność biosyntezy, natomiast niedobór tlenu bardzo wydłużał czas procesu octowania. W procesie biosyntezy uzyskano octy jabłkowe o mocy $3,3 \div 4,5$ g kwasu octowego w $100 \mathrm{~cm}^{3}$ (tab. 3), przy czym różnice statystycznie istotne wykazano pomiędzy octami z gospodarstw I i IV.

Tabela 3. Zawartość alkoholu i moc octów jabłkowych uzyskanych w procesie biosyntezy

Table 3. Content of alcohol and strength of apple vinegars produced by means of biosynthesis process

\begin{tabular}{|l|c|c|c|c||}
\hline \multicolumn{1}{|c|}{ Parametr / Parameter } & $\begin{array}{c}\text { Przedsięb. } \\
\text { rolne I } \\
\text { Farm I }\end{array}$ & $\begin{array}{c}\text { Przedsięb. } \\
\text { rolne II } \\
\text { Farm II }\end{array}$ & $\begin{array}{c}\text { Przedsięb. } \\
\text { rolne III } \\
\text { Farm III }\end{array}$ & $\begin{array}{c}\text { Przedsięb. } \\
\text { rolne IV } \\
\text { Farm IV }\end{array}$ \\
\hline $\begin{array}{l}\text { Moc octu [g kwasu octowego/100 cm } \mathrm{cm}^{3} \text { ] } \\
\text { Strength of vinegar [g of acetic acid/100 } \mathrm{cm}^{3} \text { ] }\end{array}$ & $3,3 \pm 0,2$ & $3,5 \pm 0,1$ & $4,0 \pm 0,2$ & $4,5 \pm 0,2$ \\
\hline $\begin{array}{l}\text { Zawartość alkoholu } \\
\text { Content of alcohol [\%] }\end{array}$ & $1,3 \pm 0,02$ & $<1 \%$ & $<1 \%$ & $<1 \%$ \\
\hline
\end{tabular}

Objaśnienia / Explanatory notes:

W tabeli przedstawiono wartości średnie \pm odchylenia standardowe / Table shows mean values \pm standard deviations; $\mathrm{n}=5$.

$\mathrm{Na}$ podstawie uzyskanych wyników zweryfikowano warunki technologiczne umożliwiające opracowanie procesu o najwyższej wydajności. W zależności od wydajności fermentacji alkoholowej, a następnie octowej, z $1 \mathrm{~g}$ cukrów zawartych w nastawie do fermentacji alkoholowej można otrzymać $0,4 \div 0,5 \mathrm{~g}$ kwasu octowego. Zgodnie z tym założeniem w celu otrzymania octu zawierającego ok. $5 \mathrm{~g}$ kwasu octowego w $100 \mathrm{~cm}^{3}$ zawartość cukrów w soku powinna być większa niż $10 \mathrm{~g} / 100 \mathrm{~cm}^{3}$.W opracowanej innowacyjnej metodzie z soków jabłkowych o zawartości cukrów $10,5 \div 14,7 \mathrm{~g} / 100 \mathrm{~cm}^{3}$ otrzymano octy charakteryzujące się mocą w zakresie $3,3 \div 4,5$ g kwasu octowego w $100 \mathrm{~cm}^{3}$, co świadczy o optymalizacji warunków fermentacji. Wykazano, że na moc octów statystycznie istotnie wpływała zawartość alkoholu w winie, a najefektywniejsza fermentacja octowa zachodziła przy zawartości alkoholu na poziomie $10 \%$. Ponadto zastosowanie w procesach fermentacyjnych szczepów mikroorganizmów Acetobacter pasterianus O4 i Acetobacter pasterianus MW3 pozwoliło na uzyskanie produktu o bardzo dobrych walorach smakowozapachowych. Octy jabłkowe były naturalnie mętne, odznaczały się jasnożółtą barwą oraz widocznym osadem. Charakteryzowały się niezwykle aromatycznym, owocowo- 
kwaskowym smakiem i zapachem, z lekko słodką nutą winną, bez posmaków obcych (tab. 4).

Tabela 4. Wyniki oceny sensorycznej octów jabłkowych uzyskanych w procesie biosyntezy

Table 4. Sensory evaluation results of vinegars produced by means of biosynthesis process

\begin{tabular}{|c|c|c|c|c|}
\hline $\begin{array}{l}\text { Cecha } \\
\text { Feature }\end{array}$ & $\begin{array}{l}\text { Przedsięb. rolne I } \\
\text { Farm I }\end{array}$ & $\begin{array}{l}\text { Przedsięb. rolne II } \\
\text { Farm II }\end{array}$ & $\begin{array}{c}\text { Przedsięb. } \\
\text { rolne III } \\
\text { Farm III }\end{array}$ & $\begin{array}{l}\text { Przedsięb. rolne IV } \\
\text { Farm IV }\end{array}$ \\
\hline $\begin{array}{c}\text { Klarowność } \\
\text { Clarity }\end{array}$ & \multicolumn{4}{|c|}{$\begin{array}{l}\text { Ocet naturalnie mętny, widoczny osad } \\
\text { Naturally cloudy vinegar, visible sediment }\end{array}$} \\
\hline $\begin{array}{l}\text { Barwa } \\
\text { Colour }\end{array}$ & $\begin{array}{l}\text { Jasnożółta } \mathrm{z} \text { odcieniem } \\
\text { beżowym } \\
\text { Light yellow with beige } \\
\text { shade }\end{array}$ & $\begin{array}{l}\text { Jasnożółta } \\
\text { Light yellow }\end{array}$ & & $\begin{array}{c}\text { Jasnożółta } \\
\text { z odcieniem } \\
\text { beżowym } \\
\text { Light yellow with } \\
\text { beige shade }\end{array}$ \\
\hline \multirow[b]{2}{*}{$\begin{array}{l}\text { Zapach } \\
\text { Aroma }\end{array}$} & \multicolumn{4}{|c|}{$\begin{array}{l}\text { Typowy dla octu jabłkowego, owocowy, lekko drożdżowy. Bez zapachów obcych } \\
\text { Typical for apple vinegar, fruity, slightly yeasty. No foreign odours }\end{array}$} \\
\hline & $\begin{array}{c}\text { Bardzo aromatyczny, } \\
\text { lekko kwaskowy / Very } \\
\text { aromatic, slightly acidulos }\end{array}$ & $\begin{array}{l}\text { Aromatyczny, } \\
\text { kwaskowy } \\
\text { Aromatic, acidulous }\end{array}$ & \multicolumn{2}{|c|}{$\begin{array}{l}\text { Bardzo aromatyczny, lekko } \\
\text { kwaskowy / Very aromatic, } \\
\text { slightly acidulos }\end{array}$} \\
\hline \multirow[b]{2}{*}{$\begin{array}{l}\text { Smak } \\
\text { Flavour }\end{array}$} & \multicolumn{4}{|c|}{$\begin{array}{l}\text { Typowy dla octu jabłkowego, aromatyczny, lekko słodki, lekko winny. Bez posmaków } \\
\text { obcych / Typical for apple vinegar, aromatic, slightly sweet, slightly winey. No foreign } \\
\text { aftertaste }\end{array}$} \\
\hline & $\begin{array}{l}\text { Octowo-owocowy, } \\
\text { umiarkowanie kwaśny } \\
\text { Acetic and fruity, } \\
\text { moderately acidulous }\end{array}$ & $\begin{array}{c}\text { Lekko owocowy, } \\
\text { lekko kwaśny } \\
\text { Slightly fruity, slightly } \\
\text { acidulous }\end{array}$ & \multicolumn{2}{|c|}{$\begin{array}{l}\text { Octowo-owocowy, umiarkowanie } \\
\text { kwaśny / Acetic and fruity, } \\
\text { moderately acidulous }\end{array}$} \\
\hline
\end{tabular}

Objaśnienia / Explanatory notes:

W tabeli przedstawiono wyniki zbiorczej oceny sensorycznej opracowane na podstawie wyników ocen zespołu oceniającego / Table shows results of collective sensory evaluation based on evaluation results of evaluation panel; $\mathrm{n}=5$.

Dość niska kwasowość octów umożliwia ich spożywanie bez uprzedniego rozcieńczania w wodzie, dzięki czemu cenne składniki są dostarczane do organizmu w wyjściowym stężeniu i w sposób naturalny obniżane jest pH soku żołądkowego. Zwykle wytwarzanie octu owocowego zachodzi drogą fermentacji z wykorzystaniem dzikich szczepów drożdży i bakterii kwasu octowego. Produkty te nie są stabilne pod względem cech jakościowych oraz terminu przydatności do spożycia, gdyż za każdym razem w procesie fermentacji biorą udział inne drobnoustroje. Ponadto octy są z reguły konserwowane dwutlenkiem siarki w celu wydłużenia terminu przydatności do spożycia oraz klarowane $[7,11,17,19]$, przez co nie wykazują tak aromatycznego bukietu smakowo-zapachowego jak octy uzyskane w niniejszej pracy. 
Opracowana w warunkach doświadczalnych innowacyjna metoda będzie zastosowana w gospodarstwach rolnych. Dla każdego gospodarstwa przewiduje się indywidualne zaprojektowanie zbiorników fermentacyjnych, uwzględniające możliwości lokalowe, środowiskowe i technologiczne tłoczni soków. Finalny, niepasteryzowany ocet owocowy będzie poddany badaniom pod względem składu i potencjalnych właściwości prozdrowotnych. Po uzyskaniu pierwszej partii octu jabłkowego będą podejmowane badania przechowalnicze, polegające na określeniu odpowiednich parametrów mikrobiologicznych, fizykochemicznych i sensorycznych w celu ustalenia terminu przydatności do spożycia. Wyprodukowany ocet owocowy nie będzie konserwowany chemicznie, co należy podkreślić. Produkt niepasteryzowany będzie charakteryzował się krótszym terminem przydatności do spożycia, niemniej można oczekiwać, że będzie znacznie bogatszy w substancje odżywcze i prozdrowotne.

\section{Wnioski}

1. Opracowana w Zakładzie Jakości Żywności Instytutu Biotechnologii Przemysłu Rolno-Spożywczego technologia produkcji octu jabłkowego z wykorzystaniem szczepów mikroorganizmów Acetobacter pasterianus $\mathrm{O} 4$ i Acetobacter pasterianus MW3 umożliwia otrzymanie octu jabłkowego o mocy $3 \div 4 \mathrm{~g}$ kwasu octowego $\mathrm{w} 100 \mathrm{~cm}^{3}$.

2. Wyprodukowany ocet jest naturalnie mętny, odznacza się jasnożółtą barwą, widocznym osadem, aromatycznym owocowo-kwaskowym smakiem i zapachem, z lekko słodką nutą winną, bez posmaków obcych.

3. Ocet jabłkowy nie zawiera chemicznych konserwantów, a jedynie naturalne metabolity drobnoustrojów, charakteryzuje się wysoką jakością, wynikającą z powtarzalności podstawowych cech fizykochemicznych, cech sensorycznych i mikrobiologicznych, jak również bezpieczeństwem pod względem zawartości Cd i $\mathrm{Pb}$.

4. Niska kwasowość octu umożliwia jego spożywanie bez uprzedniego rozcieńczania w wodzie, dzięki czemu cenne składniki są dostarczane do organizmu w wyjściowym stężeniu.

5. Opracowana innowacyjna technologia wytwarzania octu, przeznaczona dla indywidualnym rolników i drobnych przetwórców, może przyczynić się do zwiększenia stopnia wykorzystania lokalnych soków jabłkowych, a tym samym wpłynie na ograniczenie marnotrawienia soku wynikającego z jego krótkiego terminu przydatności do spożycia, jak również pozwoli na zwiększenie dochodowości wymienionych podmiotów. 


\section{Literatura}

[1] Antolak H.: Kwas octowy składnik żywności funkcjonalnej. Przem. Spoż., 2015, 69 (9), 41-44.

[2] Antolak H., Kręgiel D.: Bakterie kwasu octowego - taksonomia, ekologia oraz wykorzystanie przemysłowe. Żywność. Nauka. Technologia. Jakość, 2015, 4 (101), 21-35.

[3] Antolak H., Kręgiel D.: Bakterie kwasu octowego - istotne zagrożenie w przemyśle spożywczym. Przem. Spoż., 2014, 68, 12-16.

[4] Budak H.B., Guzel-Seydim Z.B.: Antioxidant activity and phenolic content of wine vinegars produced by two different techniques. J. Sci. Food Agric., 2010, 90, 2021-2026.

[5] Budak N.H., Aykin E., Seydim A.C., Greene A.K., Guzel-Seydim Z.B.: Functional properties of vinegar. J. Food Sci., 2014, 79, 757-764.

[6] Chang J., Fang T.J.: Survival of Escherichia coli O157:H7 and Salmonella enterica serovars typhimurium in iceberg lettuce and the antimicrobial effect of rice vinegar against E. coli O157:H7. Food Microbiology, 2007, 24, 745-751.

[7] Chang R.C., Lee H.C., Ou A.S.M.: Investigation of the physicochemical properties of concentrated fruit vinegar. J. Food Drug Anal., 2005, 13, 4, 348-356.

[8] Czuba J.: Octownictwo. Instytut Przemysłu Fermentacyjnego, Warszawa 1986, ss. 101-103.

[9] Fushimi T., Suruga K., Oshima Y., Fukiharu M., Tsukamoto Y., Goda T.: Dietary acetic acid reduces serum cholesterol and triacylglycerols in rats fed a cholesterol - rich diet. Br. J. Nutr., 2006, 95, 916-924.

[10] Gullo M., Caggia C., De Vero L., Giudici P.: Characterization of acetic bacteria in „traditional balsamic vinegar”. Int. J. Food Microbiol., 2006, 106, 209-212.

[11] Gullo M., Giudici P.: Acetic acid bacteria in traditional balsamic vinegar: Phenotypic traits relevant for starter cultures selection. Int. J. Food Microbiol., 2008, 125, 46-532.

[12] Jeszka M., Flaczyk E., Kobus-Cisowska J., Dziedzic K.: Związki fenolowe - charakterystyka i znaczenie w technologii żywności. Nauka. Przyroda. Technologie, 2010, 4 (2), 2-13.

[13] Johnston C.S., Buller A.J.: Vinegar and peanut products as complementary foods to reduce postprandial glycaemia. J. Am. Diet. Assoc., 2005, 105, 1939-1942.

[14] Johnston C.S., Gaas B.S.: Vinegar: Medicinal uses and antiglycemic effect. Med. Gen. Med., 2006, $8(2), \# 61$.

[15] Johnston C.S., Kim C.M., Buller A.J.: Vinegar improves insulin sensitivity to a high-carbohydrate meal in subjects with insulin resistance or type 2 diabetes. Diabetes Care, 2004, 27, 281-283.

[16] Kowalska H., Lenart A., Marzec A., Kowalska J., Samborska K., Żebrowska M.A.: Wykorzystanie produktów prozdrowotnych i suplementów diety w insulino-oporności. Post. Tech. Przetw. Spoż., 2017, 2, 46-55.

[17] Mazza S., Murooka Y.: Vinegar through the age. In: Vinegar of the World. Springer, Milan 2009, pp. 17-39.

[18] Ndoye B., Lebeccque S., Dubois-Dauphin R., Tounkanra L., Guiro A.T., Kere C., Diawara B., Thonart P.: Thermoresistant properties of acetic acid bacteria isolated from tropical products of SubSaharan Africa and destined to industrial vinegar. Enzyme Microbiol. Tech., 2006, 39, 916-923.

[19] Ou A.S.M., Chang R.C.: Taiwan fruit vinegar. In: Vinegar of the World. Springer, Milan 2009, 223241.

[20] PN-ISO 7954:1999. Mikrobiologia. Ogólne zasady oznaczania drożdży i pleśni. Metoda płytkowa w $25^{\circ} \mathrm{C}$.

[21] PN-EN 12143:2000. Soki owocowe i warzywne. Oznaczanie zawartości substancji rozpuszczalnych metodą refraktometryczną.

[22] PN-A-75101-07:1990. Przetwory owocowe i warzywne. Przygotowanie próbek i metody badań fizykochemicznych. Oznaczanie zawartości cukrów i ekstraktu bezcukrowego. 
[23] PN-EN 12147:2000. Soki owocowe i warzywne. Oznaczanie kwasowości miareczkowej.

[24] PN-EN 1132:1999. Soki owocowe i warzywne. Oznaczanie pH.

[25] PN-EN 14082:2004. Artykuły żywnościowe. Oznaczanie pierwiastków śladowych. Oznaczanie zawartości ołowiu, kadmu, cynku, miedzi, żelaza i chromu metodą atomowej spektrometrii absorpcyjnej (AAS) po mineralizacji suchej.

[26] PN-A-79120-04:1990. Wina i miody pitne. Przygotowanie próbek i metody badań. Oznaczanie zawartości alkoholu etylowego.

[27] PN-A-79120-06:1990. Wina i miody pitne. Przygotowanie próbek i metody badań. Oznaczanie zawartości cukrów.

[28] PS-13: Prosty test opisowy. Wygląd/klarowność, barwa, zapach, smak. Edycja 1. Łódź, 3 września $2012 \mathrm{r}$.

[29] Rutala W.A., Barbee S.L., Aguiar N.C., Sobsey M.D., Weber D.J.: Antimicrobial activity of home disinfectants and natural products against potential human pathogens. Infect. Control Hosp. Epidemiol., 2000, 21 (1), 33-38.

[30] Yamashita H., Fujisawa K., Ito E., Idei S., Kawaguchi N., Kimoto M., Hiemori M., Tsuji H.: Improvement of obesity and glucose tolerance by acetate in Type 2 diabetic Otsuka Long-Evans Tokushima Fatty (OLETF) rats. Biosci. Biotechnol. Biochem., 2007, 71, 1236-1243.

\section{THE USE OF FERMENTATION PROCESSES TO DEVELOP AN INNOVATIVE METHOD OF OBTAINING APPLE VINEGAR WITH HEALTH-PROMOTING PROPERTIES}

\section{$\mathrm{S} u \mathrm{~mm}$ a r y}

Fruit vinegars obtained with the use of fermentation methods constitute an interesting type of functional food, which gains increasing recognition among consumers owing to its health-promoting qualities. The objective of the research study was to develop an innovative production technology of fruit vinegar utilising local strains of microorganisms derived from the culture collection of the Institute of Agriculture and Food Biotechnology (IBPRS). The raw material used for the vinegar biosynthesis included natural, cold-pressed apple juices sourced from farmers and small agricultural employers in the Voivodeships of Łódź, Śląsk (Silesia) and Mazowsze (Mazovia). The preliminary microbiological and physical-chemical analyses of juices were conducted in order to determine the following: count of mould and yeast, content of total extract, total sugars, acidity and $\mathrm{pH}$, and content of cadmium and lead. The first production stage of vinegar was the anaerobic fermentation of apple juices to produce wines; in the wines produced the contents of alcohol and sugars were determined. The second stage was the biosynthesis of acetic acid with the use of apple wines and strains of acetic acid bacteria: Acetobacter pasterianus $\mathrm{O} 4$ and Acetobacter pasterianus MW3. During the biosynthesis process there were determined the content of alcohol and the strength of vinegar being produced. The technology of producing fruit vinegar as developed in the Food Quality Department of IBPRS made it possible to produce a product with strength ranging $3.3 \div 4.5 \mathrm{~g}$ of acetic acid per $100 \mathrm{~cm}^{3}$, with no chemical preservatives therein, showing an exceptional taste and aroma, and characterised by a high quality and nutritional value.

Key words: apple vinegar, functional food, fermentation process, Acetobacter pasterianus O4, Acetobacter pasterianus MW3 